\title{
Retinoblastoma pT2 TNM Finding v7
}

National Cancer Institute

\section{Source}

National Cancer Institute. Retinoblastoma pT2 TNM Finding v7. NCI Thesaurus. Code C88730.

Retinoblastoma with minimal optic nerve and/or choroidal invasion. (from AJCC 7th Ed.) 